УДК 793.3+792.8

\author{
Небесник Анжеліка Володимирівна \\ аспірантка, \\ Київський національний університет \\ культури і мистецть, \\ Київ, Украӥна \\ Angelicanebesnik@gmail.com
}

\title{
«КИЇВ МОДЕРН-БАЛЕТ»: АВТОРСЬКИЙ ТЕАТР І ТВОРЧА ЛАБОРАТОРІЯ
}

Мета дослідження - виявити у діяльності «Київ модерн-балету» риси авторського репертуарного театру та творчої лабораторії. Методи дослідження. Аналіз та систематизація у хронологічному порядку основних фактів мистецького пляху «Київ модерн-балету» дозволили простежити етапи еволюціонувавння його творчої діяльності. Наукова новизна полягає у вперше проведеному ретроспективному аналізі різноаспектної творчості «Київ модерн-балету», що поєднує риси репертуарного театру та балетмейстерської творчої лабораторії. Висновки. Досить умовно крізь призму ускладнення творчості «Київ модернбалету» можна провести періодизацію його діяльності: 2006-2010 pp. формування авторського репертуарного театру, виступи на міжнародних фестивалях; 2010-2013 pp. - формування та розвиток балетмейстерської лабораторії, розширення співпраці з балетними театрами України та світу; 2013-2016 рр. - поява низки вистав молодих балетмейстерів - учасників колективу у постійному репертуарі, активізація гастрольної діяльності, збільшення кількості прихильників, визнання на державному рівні. Нині «Киӥв модерн-балет» - репертуарний театр сучасної хореографіі, що $є$ одним 3 найбільш гастролюючих у країні та за ії межами, поєднує риси професійного творчого колективу та творчої лабораторії, майстерні з підготовки не лише виконавців, а й високопрофесійних балетмейстерів.

Ключові слова: «Київ модерн-балет», Поклітару Раду, балет, танець, хореографія.

Небесник Анжслика Владимировна, аспирантка Киевского национального университета культуры и искусств, Киев, Украина

«Киев модерн-балет»: авторский театр и творческая лаборатория

Цель исследования - выявить в деятельности «Киев модерн-балета» черты авторского репертуарного театра и творческой лаборатории. Методы исследования. Анализ и систематизация в хронологическом порядке основных 
фактов творческого пути «Киев модерн-балета» позволили проследить этапы эволоционирования его творческой деятельнсти. Научная новизна заключается во впервые проведенном ретроспективном анализе разноаспектного творчества «Киев модерн-балета», который сочетает черты репертуарного театра и балетмейстерской творческой лаборатории. Выводы. Достаточно условно сквозь призму усложнения аспектов творчества «Киев модерн-балета» можно провести периодизацию его деятельности: 2006-2010 гг. - формирование авторского репертуарного театра, выступления на международньх фестивалях; 20102013 гт. - формирование и развитие балетмейстерской лаборатории, распирение сотрудничества с балетными театрами Украины и мира; 2013-2016 гг. появление ряда спектаклей молодых балетмейстеров - участников коллектива в постоянном репертуаре, активизация гастрольной деятельности, увеличение количества сторонников, признание на государственном уровне. Сейчас «Киев модерн-балет» - репертуарный театр современной хореографии, который является одним из самых гастролирующих в стране и за ее пределами, сочетает черты профессионального творческого коллектива и творческой лаборатории, мастерской по подготовке не только исполнителей, но и высокопрофессиональных балетмейстеров.

Ключевые слова: «Киев модерн-балет», Раду Поклитару, балет, танец, хореография.

Nebesnyk Anzhelika, postgraduate, Kyiv National University of Culture and Arts, Kyiv, Ukraine

\section{«Kyiv Modern-Ballet»: author's theater and creative laboratory}

The purpose of the research is to define the features of an author's repertory theater and a creative laboratory in the activity of «Kyiv modern-ballet». The research methodology consisted in the analysis and systematization in the chronological order of the main facts of the artistic path of «Kyiv modern-ballet», which allowed for tracing the stages of evolution of its creative activity. The scientific novelty lies in the first conducted retrospective analysis of the multidimensional creative work of «Kyiv modern-ballet», which combines features of a repertory theater and a choreographic creative laboratory. Conclusions. Quite roughly, through the prism of complexity of the creative work of «Kyiv modernballet», it is possible to divide its activity into periods: $2006-2010$ - formation of the author's repertory theater, performances at international festivals; 2010-2013 formation and development of the choreographic laboratory, expansion of cooperation with ballet theaters of Ukraine and the world; 2013-2016 - appearance of a number of performances by young choreographers - members of the ensemble with constant repertoire, activation of touring, the increase in the number of fans, recognition at the 
state level. Nowadays, «Kyiv-modern-ballet» is a repertory theater of modern choreography, which is one of the most touring in the country and abroad, and combines features of a professional creative ensemble and a creative laboratory, as well as a workshop, training not only performers but also highly professional choreographers.

Key words: «Kyiv modern-ballet», Radu Poklitaru, ballet, dance, choreography.

Останнім часом, попри існування скептичної думки про завмирання мистецького поступу, в Україні з'являються феномени, що руйнують усталені уявлення про провінційність вітчизняного мистецтва. До подібних явищ повноправно можна віднести діяльність «Київ модерн-балету», професійного театру сучасного танцю в Україні, наукове осмислення місця та ролі якого у вітчизняній хореографічній палітрі є одним з актуальних завдань сучасної хореології. Творчість «Київ модерн-балету» $\epsilon$ одночасно відображенням загальносвітових тенденцій розвитку колективів сучасного танцю (трупи 3 яскраво вираженим авторським стилем одного балетмейстера, естетика постмодерну тощо), і демонстрацією специфіки розвитку сучасного танцо в умовах вітчизняної соціокультурної ситуації. Осмислення різнобічної діяльності колективу важливе для розуміння особливостей сучасної хореографії в Україні.

Багатий репертуар, маспттабна гастрольна діяльність, активна творча позиція художнього керівника «Київ модерн-балету» Раду Поклітару сприяють популяризації як театру, так і сучасної хореографії в цілому. Новітні підходи до втілення хореографічних творів, авангардні композиційні прийоми, нетривіальне сценографічне оформлення задають високу планку, стають прикладом для наслідування творцям усіх різновидів хореографії в Україні. Десятилітня творча історія колективу (2006-2016), накопичений емпіричний матеріал потребують комплексного розгляду, одним 3 аспектів якого е аналіз діяльності «Київ модерн-балету» як авторського колективу та творчої лабораторії.

Нині все частіше з'являються спроби аналітичного осмислення діяльності «Київ модерн-балету» в Україні та за ї̈ межами (Г. Веселовська, О. Зінич, О. Маншилін, С. Наборщикова, О. Узун, О. Чепалов та ін.), однак колектив стає об’єктом дослідження переважно публіцистичних матеріалів. Модель еволюціонування творчої діяльності «Київ модерн-балету», що поєднуе ознаки авторського репертуарного театру та творчої лабораторії, $є$ унікальною у вітчизняному хореографічному мистецтві, потребує наукового осмислення.

Мета дослідження полягає у виявленні рис авторського репертуарного театру та творчої лабораторії у діяльності «Київ модерн-балету». 
Методи дослідження. Аналіз та систематизація в хронологічному порядку основних фактів мистецького шляху «Київ модерн-балету» дозволили прослідкувати етапи еволюціонування його творчої діяльності.

Народження «Київ модерн-балету» відбулося 2006 року за ініціативи та при повному фінансуванні відомого мецената Володимира Філіппова, який, розуміючи ситуацію вакууму у сфері професійної сучасної хореографії в Україні, запропонував Р. Поклітару створити танщювальний колектив. За початковою концепцією репертуар і ху дожню стилістику «Київ модерн-балету» одноосібно визначав його головний балетмейстер і керівник Р. Поклітару.

Прем'єрним балетом для нового театрального колекгиву став «Кармен.TV» на музику Жоржа Бізе, продемонстрований 25 жовтня 2006 р. на сцені Національного академічного драматичного театру ім. Івана Франка в Києві. «Відома всім історія циганки, героїні новели Проспера Меріме, одержала у цьому балеті нове, несподіване трактування. Завдяки новаторській хореографії Р. Поклітару, сценічне життя персонажів вистави наповнилося пронизливими сучасними інтонаціями, зберігши при цьому весь шарм Іспанії XIX століття», - зазначав критик [3].

Колектив одразу, попри всі фінансові труднощі, став на шлля формування репертуарного театру сучасного танцю. «Київ модерн-балет» швидко здобув репутацію найбільш радикального театру сучасного танцю на всьому пострадянському просторі. Через рік по його створенні J. Олтаржевська писала: «Шодо перспективності цього проекту тоді «вималювалося» дві протилежні точки зору: більшість навколобалетного люду вважала, що цей театр с явищем одномоментним, нетривалим, меншість, попри все, вірила у його щасливе майбутне... За неповний рік театр випустив два балети - «Кармен.TV» та «Веронський міф. Шекспірименти». Перед «Кармен...» зняли капелюхи навіть надпринципові та, як правило, консервативно налаштовані експерти премії «Київська пектораль», назвавши саме цю виставу найкращою 3 усіх київських прем'єр 2006 року» [6].

Творчий колектив однодумців - балетмейстер Р. Поклітару, художники Ганна Іпатьєва та Андрій Злобін - створив за декілька років багатий репертуар різножанрових творів, перетворивши «Київ модерн-балет» 3 дебютанта театрального світу України на абсолютного лідера в сучасній хореографії. За перпі роки «Київ модерн-балет» пройшов шлях від колективу однієї вистави («Кармен TV» у 2006 році) до повноцінного репертуарного театру («Лускунчик» (2007), «Веронський міф: Шекспірименти» (2007), «Доп» (2007), «Болеро» (2007), «Underground» (2008), «Палата № 6» (2008), «Двое на гойдалщі» (2009), «Квартет-а-тет» (2010), «In Pivo Veritas» (2011). 
Театр не обмежувався виступами лише в Україні, активно інтегруючись у світовий хореографічний простір, беручи участь у фестивалях: у Франції («Час любити», Біарріц), Молдові («Бієнале Е. Йонеско»), Таӥланді («Фестиваль музики й танцю», Бангкок), Росії (програма «Маска плюс» фестивалю «Золота Маска», 2009 і 2010 роки, Москва; «Новіобрії» Маріїнського театру, Санкт-Петербург). Усі виступи були дуже успішними, глядачі та колеги з інших країн визнали високий художній рівень колективу.

У 2010 р. Р. Поклітару запустив всередині театру лабораторіг молодих хореографів. У репертуарі «Київ модерн-балету» 3'явився «Концерт» (Con Tutti I Strumenti), наповнення якого змінюєтьея по мірі того, як артисти готують нові роботи. Через рік після першого «Концерту» вихованці Р. Поклітару почали займати призові місця на конкурсах хореографів: 2011 р. - конкурс ім. Сержа Лифаря в Донецьку (Сергій Кон, Олена Долгих, Анастасія Харченко), 20112012 pp. - конкурс ім. С. Дягілєва в Лодзі (Сергій Кон, Олексій Бусько), 2012 р. фестиваль сучасної хореографії «IFMC» у Вітебську (Бусько, Харченко, Кон).

Творча зрілість «Київ модерн-балету» підтверджується масштабними проектами, створеними у співпраці з великими балетними театрами. У 2012 р. театр випустив дві великі прем'єри - балет «Геревень» на музику Володимира Ніколаєва (спільно з Пермським театром опери та балету) і спектакль «Перехрестя» на музику українського композитора Мирослава Скорика (спільно з Національною оперою України ім. Т. Шевченка).

«Естетика вистав Поклітару споріднена традиції балетного театру. Тільки він не продовжує іiі, а робить щось протилежне, відштовхується від балетної традиції і прагне до вироблення власного пластичної мови. Поклітару не дуже знайомі нові техніки танцю, методи композиції, способи взаємовідносин з глядачем, сформовані contemporary dance. Тут засобами танцю втілюють актуальні сюжети, перекладають на мову театру твори сучасної академічної музики, інтерпретують класичні балетні тексти», - заявляе О. Маншилін [5, с. 259-260]. Досить сміливим видається зауваження щодо необізнаності Р. Поклітару у нових техніках (які, до речі, досить часто народжуються, видозмінюються, втрачають будь-який сенс не виходячи за межі танцювальних студій, де були створені). Особливо дивною виглядас спроба применшити балетмейстерську вартість постановок, адже досить часто саме Р. Поклітару в Україні стає тим авангардом у композиційних прийомах, які наслідують інші хореографи.

Протягом тривалого часу балетмейстер Р. Поклітару винопував ідею постановки про живу Істоту, яка не може існувати, якщо проти іï волі переробляють їі сутність. Задум був реалізований у червні 2013 р. у виставі «Лебедине озеро. Сучасна версія». Вистава навмисно контрастує з першодже- 
релом - історією про принца, що покохав дівчину-лебідь, набуваючи ознак притчі про неможливість жити, зраджуючи свосму істинному єству. Існування у неприродній спосіб призводить лише до катастрофи - життя головного героя, що може лише мріяти про справжні почуття, бачити повноцінне життя уві сні, трагічно обривається.

Поступово, зі зростанням балетмейстерської майстерності артистів «Київ модерн-балету» у репергуарі театру з'явилися їхні постановки, що стало можливим завдяки позиції Р. Поклітару, який не боїться конкуренції та порівнянь зі своӥми творами, дає можливість реалізуватися молодому поколінню, розуміючи, що це єдиний правильний шлях для формування пирокого поля сучасної хореографії в Україні. Практично з 2010 р., моменту потрапляння до «Київ модерн-балету» творів, поставлених не Р. Поклітару, тенденція урізноманітнення репертуару за рахунок постановок артистів, однодумців та послідовників Р. Поклітару, зміцнюеться.

Одним з найяскравіших виконавців та балетмейстерів, чий талант зміцнів у «Київ модерн-балеті», можна назвати Олексія Буська (протягом 9-ти років) соліста театру. 2013 р. він поставив балет на одну дію у чотирьох картинах «Пори року. Кохання, як воно є» на музику О. Родіна. Прем'сра наступного балету О. Буська «Видіння рози» відбулася 18 червня 2014p. на одному вечорі 3 прем'єрою одноактного балету-драми Р. Поклітару «Жінки в ре-мінорі» (за п’єсою Федеріко Гарсія Лорки «Дім Бернарди Альби», що для молодого балетмейстера було дуже відповідальним

Р. Поклітару схвально відгукусться про свого артиста - талановитого Олексія Буська: «Веі хореографічні рішення не вдається продумувати заздалегідь. Коли ми ставимо балет на майданчику, кожен висловлює свої пропозиції. 3 Олексієм узагалі окрема історія: я йому одну ідею - він мені натомість п'ять» [8]. Всесвітньо відома романтична історія на музику Карла Марії фон Вебера, створена у «Російських сезонах» Дягілева Михайлом Фокіним, кардинально переосмислена О. Буськом у найкращих традиціях постмодерну, перетворившись на трагедію. «Коли починав ставити «Видіння Рози», думав, що це історія про дівчину. Під час роботи я зрозумів, що це балет про матір, яка присвятила все життя дочці. Це історія про страждання душі, відносини між рідними людыми та смерть», - розповідас Олексій Бусько [8].

Широкого резонансу та великого успіху зазнав балет-роздум про швидкоплинність життя на одну дію на музику А. Вівальді за мотивами однойменної п’єси Торнтона Вайлдера «Довгий різдвяний обід», створений Р. Поклітару наприкінці 2014 р. Головна сюжетна лінія п'єси оповідає про 90 років із життя родини Байярдів, що проносяться у вигляді різдвяних обідів. У низці застіль і святкувань проходять перед глядачем долі людей. Немов метеликиодноденки вони зникають помираючи, не залишивши після себе нічого, що дало б привід згадати про них наступним поколінням [2]. 
Улітку 2015 р. відбулася прем’сра балету Артема Шошина «Ближче, ніж кохання». За думкою Г. Веселовської, «головною наснагою для Артема Шошина $\epsilon$ власний повсякденний життєвий досвід, а тому його танцювальна лексика формуеться із великої кількості буденних рухів, пластики птахів, плазунів, хижаків. Три чоловічо-жіночі танцювальні пари, доволі нерівноцінні за виконавським рівнем: кожна, у власний спосіб переплітаючи тіла, руки, ноги, представляють стани подружнього існування, скульптурно карбуючи психологічноемоційну напруженість» [1]. Досить категорично мистецгвознавець висловлюється про танцювальну лексику: «... кожний рух танцівники наче виштовхують із гімнастичною вправністю, пробивають акробатичними трюками шлях у щільному просторі, який є лише повітрям. Відтак, момент виконання певної хореографії, що інколи в «Київ модерн-балеті» уподібнюється роботі, так і залишається проблемним для цього колективу. Або, можливо, у Р. Поклітару просто краще виходить вирощування хореографів, а не танцівників, які втілювали 6 їхні задумџ» [1]. Різке ставлення до рівня виконавської майстерності окремих артистів театру частково $є$ виправданим, адже визначальними критеріями відбору танцівників для Р. Поклітару є рівень акторської обдарованості, сценічної розкутості, а не балетної навченості. Також економічні обставини (театр існує в умовах відсутності державного фінансування, недостатньої підтримки меценатів) не дають можливості запрошувати всіх виконавців високого рівня. Можливо, наступним кроком Р. Поклітару на пाляху розвитку колективу стане створення танцювальної студії при «Київ модерн-балеті», що дасть можливість готувати виконавців спеціально для театру.

У квітня 2016 р. відбулася грандіозна прем'єра балету Р. Поклітару «Жизель» на сцені Жовтневого палацу в Києві. На думку О. Чепалова, «цікаво, що у версії хореографа всі імена героїв балету збережені, але ї приналежність відноситься до сучасного соціуму. Граф Альберт і його наречена Батильда потрапили в одну компанію байкерів, мстива Мірта зі сцени на кладовищі в балеті XIX ст. стала ... власницею борделя, а віліси (тіні романтичних наречених, які померли до весілля) перетворилися на... повій... Поклітару перетворює сумнівний сюжет в соціально-психологічну драму. Балетмейстер, він же режисер (у Раду ці якості професії щасливо об'єдналися) переконує авторською концепцією, де танець підгримує драматургічну основу видовища [9].

Подібні масштабні постановки, що потребують спеціально облаштованих великих сценічних майданчиків і не можуть бути реалізовані в умовах базової сцени Киӥвського муніципального академічного театру опери та балету для дітей та юнацтва, де вистави «Київ модерн-балету» посідають значну частину репертуару, зайвий раз свідчать не лише про зрілість балетмейстера, а й сформованість і широкий діапазон творчих можливостей трупи. 
Наприкінці 2016 р. у репертуарі «Київ модерн-балету» з'явилася дебютна вистава Анатолія і Катерини Водзянських «Second Floor» («Другий поверх») на музику англійця Джеймса Блейка, аргентинця Густава Сантаолалья та німця Нільса Фрама. За словами молодої пари, що виступила в якості постановників, хореографів та авторів лібрето, сюжет сформувався у спільних бесідах про взаємини між чоловіками і жінками, а героями стали прототипи самих танцівників - учасників балету: «Все народжувалося на репетиціях. Ми відштовхувалися у першу чергу від себе самих, свого світосприйняття. В основу було покладене бажання танцювати те, щцо нам близьке по духу, за стилем і манерою подачі, так, як ми відчуваємо танець... У нашому розумінні «другий поверх»- це такий собі видуманий простір для з'ясування певних відносин» [4].

Технологія постановки «Second Floor» $\epsilon$ яскравою демонстрацією лабораторії творчого процесу всередині колективу «Київ модерн-балет», де створено умови для реалізації балетмейстерського потенціалу танцівників.

Балет «Second Floor» Катерини і Анатолія Водзянських отримав II премію на XXIX Міжнародному фестивалі сучасної хореографії «IFMC» 2016 р. у Вітебську (Білорусь).

Ще один творчій обрій колективу «Київ модерн-балет» відкрився 2014 р., коли 3 метою популяризації хореографічного мистецтва в Україні, впливу на формування естетичних смаків глядачів шляхом знайомства із кращими здобутками сучасного хореографічного мистецтва, підвищення фахового рівня виконавської майстерності танцівників, виявлення молодих талановитих виконавців та балетмейстерів було організовано фестиваль хореографічного мистецтва «KMATOБ-FEST» (одним з організаторів якого виступив О. Бусько). Фестиваль уже було проведено тричі у травні $(2014,2015,2016)$ [7].

У жовтні 2016 р. театр відзначив свій десятирічний ювілей у статусі потужного професійного колективу сучасної хореографії, що набув популярності у багатьох країнах світу, перетворивея з транслятора творчих ідей одного балетмейстера на справжню творчу лабораторію молодих хореографів.

У 2016 р. Р. Поклітару за балети «Лебедине озеро», «Жінки в ре мінорі», «Довгий різдвяний обід» і балет-триптих «Перехрестя» у номінації «музичне мистецтво» став лауреатом Національної премії України імені Тараса Шевченка.

Наукова новизна полягає у вперше проведеному ретроспективному аналізі різноаспектної творчості «Київ модерн-балету», акцентуванні на дуалістичній сутності колективу, що посднує риси репертуарного театру та балетмейстерської творчої лабораторії.

Висновки. Досить умовно крізь призму ускладнення творчості «Київ модерн-балету» можна провести періодизацію його діяльності: перший етап (2006-2010) - формування авторського репертуарного театру, виступи на між- 
народних фестивалях; другий етап (2010-2013) - формування та розвиток балетмейстерської лабораторії, розширення співпраці з балетними театрами України та світу; третій етап (2013-2016) - поява низки вистав молодих балетмейстерів - учасників колективу у постійному репертуарі, активізація гастрольної діяльності, збільшення кількості прихильників, визнання на державному рівні. Огже, десятиліття «Київ модерн-балет» зустрів у статусі репертуарного театру сучасної хореографії, що є одним з найбільш гастролюючих у країні та за ії межами, посднавши риси професійного творчого колективу та лабораторії для експериментувань молодих хореографів.

\section{Список використаних джере.}

1. Веселовська Г. І. «Ближче, ніж кохання» - стосунки двох [Електронний ресурс] / Г. І. Веселовська // День. - 2015. - 15 червня. - Режим доступу : https://www.musictheatre.kiev.ua/print/press/170/. - Назва з екрану.

2. Довгий різдвяний обід [Електронний ресурс] // Київ модерн-балет. Режим доступу : https://www.musictheatre.kiev.ua/ua/performance/130. - Назва 3 екрану.

3. Кармен. TV [Електронний ресурс] // Київ модерн-балет. - Режим доступу : https://www.musictheatre.kiev.ua/ua/performance/100. - Назва з екрану.

4. Котенок В. Листи до половинки i пошук кохання [Електронний pecypc] / В. Котенок // День. - 2016. - 1 грудня. - Режим доступу : https://day.kyiv.ua/uk/article/kultura/lysty-do-polovynky-i-poshuk-kohannya. Назва 3 екрану.

5. Маншилин А. Украина. Разные мнения о наличии / А. Маншилин // Современный танец постсоветского пространства / Е. Васенина. - Москва, 2013. - С. 245-275. - (Балетный круг).

6. Олтаржевська Л. Раду Поклітару: «Я - не тиран. Але й не демократ» / Л. Олтаржевська // Україна молода. - 2007. - 14 вересня. - С. 3.

7. Положення про проведення фестивалю хореографічного мистецтва «КМАТОБ-FEST» [Електронний ресурс]. - Режим доступу : https://www.music theatre.kiev.ua/ua/performance/115. - Назва з екрану.

8. Устиловська I. Раду Поклітару та його жінки [Електронний ресурс] / I. Устиловська // Україна молода. - 2014. - 12 червня. - Режим доступу http://www.umoloda.kiev.ua/number/2475/164/87839/. - Назва з екрану.

9. Чепалов А. Радикальная «Жизель» [Электронный ресурс] / А. Чепалов // День. - 2016. - 13 апреля. - Режим доступа : https://day.kyiv.ua/ru/article/kultura/ radikalnaya-zhizel. - Назва з екрану. 


\section{References}

1. Carmen. TV. (2006). Kiev modern-ballet [online]. Available at: $<$ https://www.musictheatre.kiev.ua/ua/performance/100> [Accessed 23 October 2006].

2. Chepalov, A. (2016). Radical «Giselle». Den, [online]. Available at: $<$ https://day.kyiv.ua/ru/article/kultura/radikalnaya-zhizel> [Accessed April 13th 2016].

3. Kotenok, V. (2016). Letters to the half and search for love. Kyiv modernbalet, [online]. Available <at:https://day.kyiv.ua/uk/article/kultura/lysty-dopolovynky-i-poshuk-kohannya> [Accessed December 12016 ].

4. Long Christmas Lunch. (2014). Kyiv modern-ballet, [online]. Available at: $<$ https://www.musictheatre.kiev.ua/ua/performance/130> [Accessed 23 October 2014].

5. Manshilin, A. (2013). Ukraine. Different opinions on the availability. Sovremenmy tanets postsovetskogo prostranstva [Modern Dance in the former Soviet Union], pp. 245-275.

6. Oltarzhevska, L. (2007). Radu Poklitaru: «I am not a tyrant. Yet not a democrat. Ukraina moloda, [Young Ukraine], p. 3.

7. Regulations on conducting the festival of choreographic art «KMATOBFEST» (2014). Kiev modern-ballet, [online]. Available at: <https://www.music theatre.kiev.ua/ua/performance/115>[Accessed 23 October 2014].

8. Ustylovska, I. (2014). Radu Poklitaru and his women. Ukraina moloda, [online]. Available at: <http://www.umoloda.kiev.ua/number/2475/164/87839/> [Accessed June 12 2014].

9. Veselovska, G.I. (2015). «Closer than love» - the relationship of two. Den, [online]. Available at: $<$ https://www.musictheatre.kiev.ua/press $/ 170>$ [Accessed June 15th 2015].

(C) Небесник A. В., 2016 